\title{
Occurrence and biology of Pseudogonalos hahnii (Spinola, 1840) (Hymenoptera: Trigonalidae) in Fennoscandia and the Baltic states
}

\author{
Simo Väänänen, Juho Paukkunen, Villu Soon \& Eduardas Budrys
}

Väänänen, S., Paukkunen, J., Soon, V. \& Budrys, E. 2018: Occurrence and biology of Pseudogonalos hahnii (Spinola, 1840) (Hymenoptera: Trigonalidae) in Fennoscandia and the Baltic states. - Entomol. Fennica 29: 86-96.

Pseudogonalos hahnii is the only known species of Trigonalidae in Europe. It is a hyperparasitoid of lepidopteran larvae via ichneumonid primary parasitoids. Possibly, it has also been reared from a symphytan larva. We report the species for the first time from Estonia, Lithuania and Russian Fennoscandia, and list all known observations from Finland and Latvia. An overview of the biology of the species is presented with a list of all known host records.

S.Väänänen, Vantaa, Finland; E-mail: svaanan2@welho.com

J. Paukkunen, Finnish Museum of Natural History, Zoology Unit, P.O. Box 17, FI-00014 University of Helsinki, Finland; E-mail: juho.paukkunen@helsinki.fi

V. Soon, Natural History Museum, University of Tartu, Vanemuise 46, 51014 Tartu,Estonia; E-mail: villu.soon@ut.ee

E. Budrys, Nature Research Centre, Akademijos 2, LT-08412 Vilnius, Lithuania; E-mail:ebudrys@ekoi.lt

Received 27 June 2017, accepted 22 September 2017

\section{Introduction}

Trigonalidae is a moderately small family of parasitic wasps of little over 100 species and about 20 genera (Carmean \& Kimsey 1998, Chen et al. 2014). They are mainly found in the tropics and subtropics (Carmean \& Kimsey 1998). Five species have been described from the Nearctic (Smith \& Stocks 2005) and around two dozen species from the Palaearctic (Lelej 2003, Chen et al. 2014). Only one species occurs in Europe (Madl 2013). Trigonalidae clearly belong to Parasitica, but morphologically they possess some features that are reminiscent of Aculeata and Symphyta. For example, head shape, mouthparts and tarsal plantulae are shared with Symphyta and general body shape and terminal ovipositor with Aculeata (Weinstein \& Austin 1991). The trigonalid ovipositor is reduced and hidden within the abdomen and it is not known if it is used in egg placement (Quicke et al. 1999).

In the past, Trigonalidae have been variously placed within or near almost all other apocritan lineages (Carmean \& Kimsey 1998) and they have been considered to be phylogenetically close to Evanioidea, Megalyroidea, Ceraphronoidea or Aculeata (Sharkey 2007, Klopfstein et al. 2013). Evidence, both morphological and molecular, is mounting that Trigonalidae are closely related to stinging wasps (Aculeata) and Evanioidea (Klopfstein et al. 2013, Zimmermann \& Vilhelmsen 2016, Branstetter et al. 2017, Peters et al. 2017). Trigonalidae is also closely related to the extinct Cretaceous family Maimetshidae 
(Vilhelmsen et al. 2010, Perrichot et al. 2011) which is currently also placed in superfamily Trigonaloidea (Aguiar et al. 2013). Asymmetrical mandibles (not present in all maimetshids) and female tarsal plantulae unite these two families, but maimetshids differ from Trigonalidae by their exserted ovipositor and missing antennal tyloids (Vilhelmsen et al. 2010, Perrichot et al. 2011). The oldest fossils of true Trigonalidae are known from French Albian Amber (100 to 113 mya) (Nel et al. 2003).

Almost all trigonalid species are hyperparasitoids, attacking Ichneumonidae (Hymenoptera) and Tachninidae (Diptera) (referred in this paper as primary hosts) that parasitize leaffeeding lepidopteran or symphytan larvae (referred in this paper as secondary hosts). Two Australian species develop as primary parasitoids of sawflies (Weinstein \& Austin 1991). One trigonalid species has been reared from a tachinid developing on a detrivorous crane fly (Diptera: Tipulidae) larva (Gelhaus 1987). Trigonalid females are very fecund and oviposit thousands of eggs along or within the margins of plant leaves. The eggs in turn are by chance ingested by lepidopteran or symphytan larvae (Carmean 1991, Weinstein \& Austin 1991). The eggs have never been observed to have been purposefully oviposited near host animals (Schnee 2011). Among parasitoids, only some tachinid flies are known to depend on this same method of host ingestion to reach their hosts (Stireman et al. 2006). Mechanical and chemical stimuli incite the $1^{\text {st }}$ instar trigonalid larva to hatch and it bores through the secondary host larva's gut wall to search for a primary ichneumonid or tachinid parasitoid larva present within the secondary larva's hemocoel, after which it develops as a hyperparasitoid (Weinstein \& Austin 1991). Trigonalid larval development is then delayed until the ichneumonid or tachinid primary host pupates or is near pupation, after which the trigonalid larva consumes the primary host. The first three trigonalid larval instars are endoparasitic while the fourth and fifth instars are ectoparasitic after which pupation takes place. The third instar has a heavily chitinized head and formidable mandibles, suggesting that it uses them to fight and kill other possible parasitoid larvae it encounters within the host. After eclosion, the adult uses its strong mandibles to cut through the host cocoon, pupa or puparium (Weinstein \& Austin 1991). Some Trigonalidae species depend on their eggs being brought with phytophagous larvae into nests of social vespids, where they develop as primary parasitoids of vespid larvae (Weinstein \& Austin 1991). In addition to Trigonalidae, only a few Hymenoptera groups (Eucharitidae, Perilampidae, Ichneumonidae: Eucerotinae) oviposit their eggs away from hosts but these groups have planidial larvae, i.e. larvae that actively seek and enter the host animal (Heraty \& Murray 2013, Shaw 2014). Likewise, some elampine cuckoo wasps (Hymenoptera: Chrysididae) oviposit into free-living aphids and depend on digger wasp (Hymenoptera: Crabronidae) females to prey on and carry these aphids into their nests, wherein the elampine larvae develop as parasitoids on crabronid progeny (Winterhagen 2015).

Pseudogonalos Schulz, 1906 is a palaearctic genus that includes three valid species: Pseudogonalos hahnii (Spinola, 1840), P. harmandi Schulz, 1906 and P. angusta Chen, van Achterberg, He \& Xu, 2014 (Carmean \& Kimsey 1998, Chen et al. 2014). Only a single and now lost $P$. harmandi specimen is known from Darjeeling, North-Eastern India (Carmean \& Kimsey 1998). Recently, Chen et al. (2014) described a third Pseudogonalos species from China (Inner Mongolia), P. angusta Chen, van Achterberg, He \& $\mathrm{Xu}, 2014$. Pseudogonalos hahnii is a widespread but rare palaearctic species, and it is the only European species of the family (Lelej 2003, Schnee 2011).

Pseudogonalos hahnii is a black species with dark spotted fore wings. The habitus (Fig. 1) is reminiscent of some aculeate wasps, e.g. a pemphredine sphecid. It can be separated from the other hymenopterans in the region by the combination of various characters: characteristic fore wing venation with 10 developed cells and welldeveloped costal cell, hind wing with 2 cells, raised crests near the point of antennal insertions on the middle of the face, antennae with 26-27 segments, mandibles with 3-5 large teeth, presence of tarsal plantar lobes on tarsal segments and cleft tarsal claws (Gauld \& Bolton 1988, Chen et al. 2014).

In this article, we review the biology and distribution of the only European trigonalid spe- 


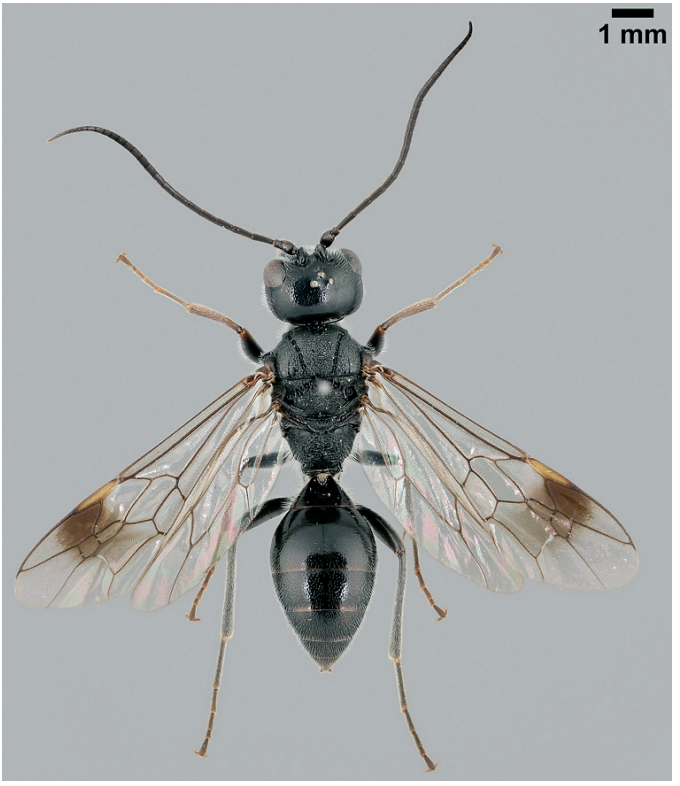

Fig. 1. Habitus of Pseudogonalos hahnii. Specimen collected from Parikkala, Finland. Photo: Pekka Malinen.

cies $P$. hahnii in Fennoscandia and the Baltic states.

\section{Materials and methods}

We compiled all published records of Pseudogonalos hahnii from the study region and gathered data from the following public and private collections:

Institute of Agricultural and Environmental Sciences, Estonian University of Life Sciences [former Institute of Zoology and Botany], Tartu, Estonia (IZBE)

Entomological collection of the Nature Research Centre, Vilnius, Lithuania (NRC)

Finnish Museum of Natural History, University of Helsinki, Finland (MZH)

Natural History Museum, University of Tartu, Estonia (TUZ)

Private collection of Ali Karhu (Coll. Karhu)

Private collection of Juha Pöyry (Coll. Pöyry)

Private collection of Martti Koponen (Coll. Koponen)

Private collection of Mikk Heidemaa (Coll. Heidemaa)
Private collection of Reima Leinonen and Guy Söderman (Coll. Leinonen \& Söderman)

Private collection of Veli Vikberg (Coll. Vikberg)

Two Finnish specimens were DNA barcoded by the Canadian Centre for DNA barcoding (CCDB) and their DNA barcode sequences were deposited in the BOLD systems database. They are available from GenBank through the accession numbers MF040884 and MF04088 (Digital Object Identifier (DOI): dx.doi.org/10.5883/DSPSEHAH)

There has been some dispute about the correct spelling of the family ("Trigonalidae" vs. "Trigonalyidae") and superfamily ("Trigonaloidea" vs. "Trigonalyoidea") names. We follow Carmean and Kimsey (1998) and use Trigonalidae as done recently by Aguiar et al. (2013), Madl (2013) and Broad (2016). For differing opinions, see Lelej (2003) and Chen et al. (2014). For nomenclature of host species, we follow Fauna Europaea (de Jong et al. 2014).

\section{Results}

Synonymy and records of Pseudogonalos hahnii from Fennoscandia and the Baltic states are presented below. The records are listed in chronological order within countries, and the acronyms in parentheses refer to specimen depositories. Coordinates are given in the WGS84 system. The symbol $\sim$ indicates that the coordinates were estimated from the locality name.

Pseudogonalos hahnii (Spinola, 1840)

Trigonalys hahnii Spinola, 1840

Trigonalis anglicana Shuckard, 1841

Trigonalis macquartii Guérin, 1842

Trigonalis nigra Westwood, 1843

Trigonalis aterrima Eversmann, 1849

Trigonalis nigra var. solitaria Jacobs, 1878

Trigonalis hahni var. phaeognatha Enderlein, 1905

Trigonalis hahni var. enslini Torka, 1936

Trigonalis prudnicensis Torka, 1936

Estonia: 1 ภ, Uderna ( 58.183N, 26.400E), 24.VII.1988, leg. Kalle Remm (IZBE, id: 
IZBE0722218); 1 ㅇ, Elva ( 58.225N, 26.416E), 3.VII.1992, leg. Kalle Remm (IZBE, id: IZBE0722219); 1 \%, Sirgala $(\sim 59.283 \mathrm{~N}$, 27.717E), 15.VII.2004, leg. Villu Soon (TUZ, id: TUZ055034); 1 q, Luunja park ( 58.356N, 26.883E), 21.VII.2005, leg. Kaupo Elberg (IZBE, id: IZBE0722220); 1 +, Järvselja ( $58.269 \mathrm{~N}, 27.309 \mathrm{E}), 2$. VIII.2005, leg. Villu Soon (TUZ, id: TUZ055031); 1 ㅇ, Tartu, Tüki $(58.409 \mathrm{~N}, 26.530 \mathrm{E})$, margin of mixed forest (near flooded area), Malaise trap, 4.12.VII.2007, leg. Mikk Heidemaa (Coll. Heidemaa); 1 q and 3 ふ઼, Vehendi $(58.231 \mathrm{~N}$, 26.155E), Malaise trap, 3.-9.VII.2010, leg. Villu Soon (TUZ, ids: TUZ055029, TUZ055030, TUZ055033, TUZ055038); 1 , Vehendi $(58.231 \mathrm{~N}, 26.155 \mathrm{E}), \quad$ Malaise trap, 16.24.VII.2010, leg. Villu Soon (TUZ, id: TUZ055032); 1 ㅇ, Sõõru 1 km NW (58.651N, 26.892E), Malaise trap, 25.VI-4.VII.2011, leg. Villu Soon (TUZ, id: TUZ055035); 2 우, Sõõru $1 \mathrm{~km} \mathrm{NW}(58.651 \mathrm{~N}, 26.892 \mathrm{E})$, Malaise trap, 4.21.VII.2011, leg. Villu Soon (TUZ, ids:

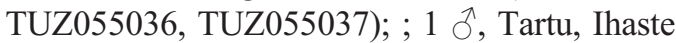
(58.349N, 26.771E) 23.IX.2017, leg. Villu Soon (TUZ, id: TUZ108320). Total 10 females and 5 males.

Finland: 1 을 Helsinki, Fredriksberg (= Pasila) $(\sim 60.197 \mathrm{~N}, 24.931 \mathrm{E})$, on a leaf of Salix caprea, 28.VII.1943, leg. Adolf Nordman (MZH); 1 ㅇ, Finby (= Särkisalo), Vedudden $(\sim 60.112 \mathrm{~N}$, 22.953E), 9.VII.1948, leg. Rabbe Elfving $(\mathrm{MZH}) ; 1$, Vanaja $(\sim 60.978 \mathrm{~N}, 24.503 \mathrm{E})$, 10.VII.1949, leg. Erkki Valkeila (MZH); 1 ㅇ, Lohja ( $60.251 \mathrm{~N}, 24.066 \mathrm{E})$, on a leaf of Ribes, 26.VII.1954, leg. Erkki Rantalainen (MZH); 1 , , Helsinki, Haaga ( 60.221N, 24.896E), 23.VII.1969, leg. Jonny Perkiömäki (Coll. Vikberg); 1 q, Lohja, Vappula, Jusola (60.215N, 23.984E), rocky meadow, 2.VII.2004, leg. Juha Pöyry (Coll. Pöyry); 1 +, Lohja, Hiitti (60.275N, 24.032E), dry meadow, 20.VII.2004, leg. Juho Paukkunen (MZH, http://id.luomus.fi/GP. 70893); 1 \%, Mikkeli, Otava (61.626N, $27.066 \mathrm{E})$, house yard or road verge, 5.VII.2005, leg. Martti Koponen (Coll. Koponen); 1 ㅇ, Parikkala, Melkoniemi, Peltola (61.529N, 29.377E), meadow, 7.VII.2007, leg. Pekka Malinen \& Tomi Salin (MZH); 1 q, Nastola,
Lemo (61.062N, 25.836E), 24.VII.2008, leg. Tomi Salin (MZH, http://id.luomus.fi/ GP.71215); 1 †, Liperi, Käsämä (62.634N, 29.330E), bog, Malaise trap, 30.VI-4.VII.2012, leg. Ali Karhu (Coll. Karhu, http://id.luomus.fi/ GP.96316); 1 Oे, Janakkala, Kalpalinna, Turistirinne (60.928N, 24.592E), 24.VIII.2012, leg. Veli Vikberg (Coll. Vikberg); 1 đ, Janakkala, Kalpalinna, Turistirinne (60.927N, 24.594E), 12.VII.2013, leg. Veli Vikberg (Coll. Vikberg); 1 †, Tohmajärvi, Jalajanvaara $(62.207 \mathrm{~N}$, 30.316E), meadow, 19.VII.2013, leg. H. Hokkanen, G. Söderman \& R. Leinonen (Coll. Leinonen \& Söderman); 1 , Janakkala, Kalpalinna, Turistirinne (60.929N, 24.593E), 25.VII.2016, Veli Vikberg (visual observation). Total 12 females and 3 males.

Latvia: 1 , Riga district, Salaspils ( $56.861 \mathrm{~N}$, 24.349E), 7.VII.1981, leg. Z. Spuris (Abenius \& Spungigis 2001); 1 †, Lubāns lake area, ( $56.818 \mathrm{~N}, \quad 26.907 \mathrm{E}), \quad 14 . \mathrm{VII} .2017$, photographed by Ugis Piterāns. Total 2 females.

Lithuania: 1 , Vilnius, Jeruzale $(\sim 54.742 \mathrm{~N}$, 25.283E), 1.VIII.1967, leg. Algimantas Jakimavičius (NRC); $2 \hat{\jmath}$, Vilnius, Vingis park ( 54.684N, 25.229E), 4.VII.1970, leg. Algimantas Jakimavičius (NRC); 1 , Vilnius, Sapieginè ( 54.706N, 25.339E), 1.V.1973, leg. Algimantas Jakimavičius (NRC); 1 गे, Vilnius, Žemieji Paneriai ( $54.642 \mathrm{~N}, 25.195 \mathrm{E})$, 21.VI.1974, leg. Algimantas Jakimavičius (NRC); 1 +, Vilnius, Jeruzalè $(\sim 54.742 \mathrm{~N}$, 25.283E), 8.VIII.1974, leg. Algimantas Jakimavičius (NRC); 1 ô, Vilnius, Jeruzalè $(\sim 54.742 \mathrm{~N}, \quad 25.283 \mathrm{E}), \quad 12 . \mathrm{VI} .1975, \quad$ leg. Algimantas Jakimavičius (NRC); 1 ô, Vilnius $(\sim 54.680 \mathrm{~N}, 25.320 \mathrm{E}), 12 . \mathrm{VI} .1975$, leg. Algimantas Jakimavičius (NRC); 1 ô, Vilnius, Jeruzalè ( $\sim 54.742 \mathrm{~N}, 25.283 \mathrm{E})$, 5.IX.1975, leg. Algimantas Jakimavičius (NRC); 1 ㅇ, Vilnius, Pilaitė ( 54.700N, 25.190E), 11.VIII.1976, leg. Vytautas Jonaitis (NRC); 1 đ, Žiežmariai ( 54.820N, 24.450E), 15.VI.1977, leg. Aldona

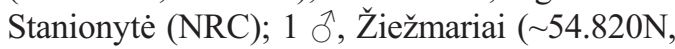
24.450E), 20.VI.1978, leg. Algimantas Jakimavičius (NRC); 1 q, Pasmalvès $(\sim 55.617 \mathrm{~N}$, 26.417E), 29.VI.1988 leg. Eduardas Budrys (NRC); 1 †, Smukučiu šilelis forest $(\sim 55.089 \mathrm{~N}$, 


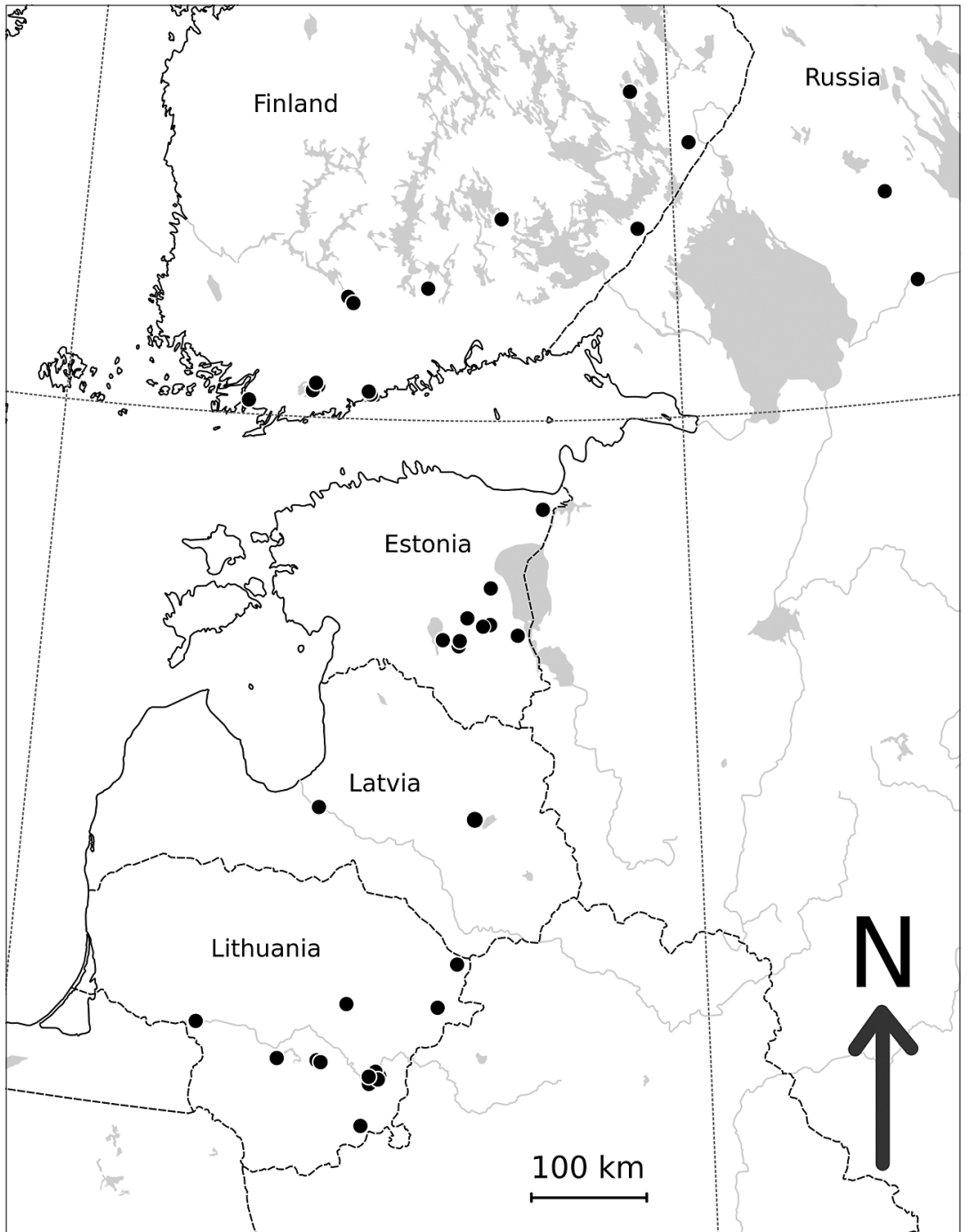

Fig. 2. Distribution of Pseudogonalos hahnii in Fennoscandia and the Baltic countries.
22.721E), 9.VII.1998 leg. Vytautas Jonaitis (NRC); 1 गे, Strošiūnai reserve $(\sim 54.806 \mathrm{~N}$, 24.508E), 15.VII.1998 leg. Vytautas Jonaitis (NRC); 1 ๙ , Akmeniškiai ( 55.267N, 26.145E), 08.VII.1999 leg. Vytautas Jonaitis (NRC); 2 , Papiškès ( $\sim 54.302 \mathrm{~N}, 25.092 \mathrm{E})$, 9.VII.1999 leg. Vytautas Jonaitis (NRC); 1 q, Garliava ( $\sim 54.825 \mathrm{~N}, 23.890 \mathrm{E}), 28$. VII.1999 leg. Vytautas Jonaitis (NRC); 1 ô, Dukstyna reserve ( 55.281N, 24.846E), 19.VII.2000 leg. Vytautas Jonaitis (NRC). Total 9 females and 11 males.

Russian Fennoscandia: 1 q, Vazhiny, Svir, ( 60.961N, 34.021E), 8.VII.1942, leg. Viljo J. Karvonen (MZH); 1 q, Pryazha, $(\sim 61.692 \mathrm{~N}$,
33.622E), 1943, leg. Paavo Kontkanen (MZH). Total 2 females.

A total of 54 P. hahnii specimens are known from the study region. Of these 35 are females and 19 males. The species is here reported from Estonia, Lithuania and Russian Fennoscandia for the first time. The only known Latvian record until 2017 was from 1981 (Abenius \& Spungisis 2001). The species was originally reported from Finland in a short meeting report, which did not include detailed information of collecting sites (Anonymous 1950).

The DNA barcode sequences of the two Finnish specimens were identical. No other DNA barcodes of $P$. hahnii have been deposited in the 
Fig. 3. Habitat of Pseudogonalos hahnii in Finland (Parikkala, Melkoniemi). Photo: Juho Paukkunen.

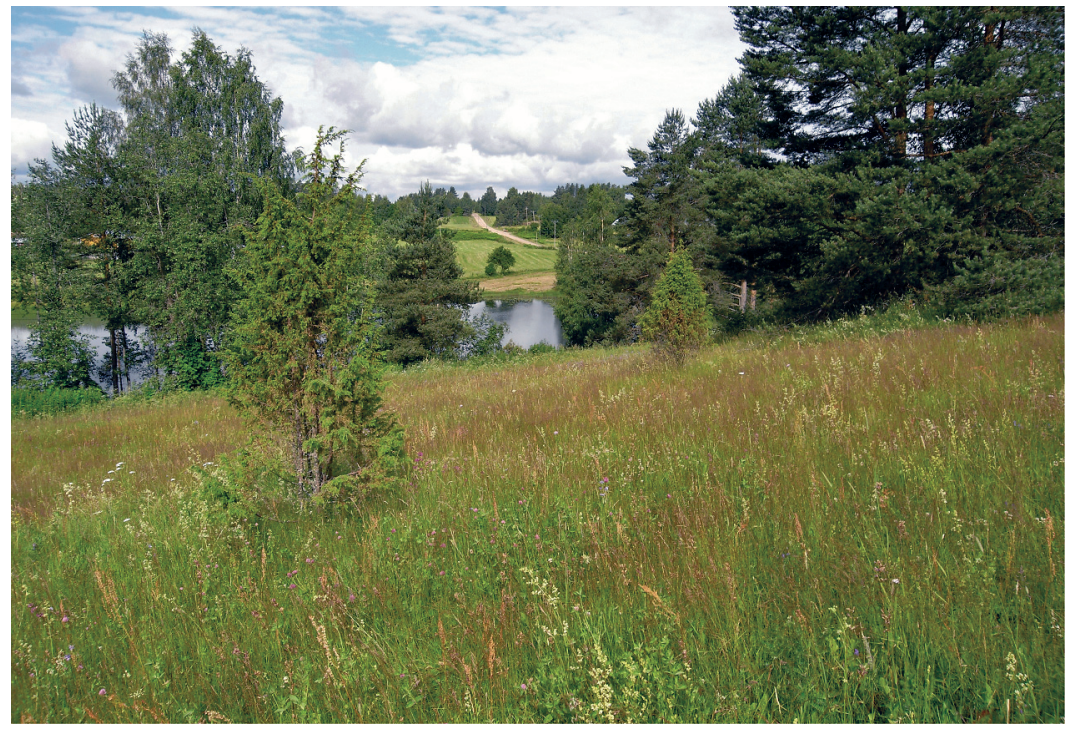

BOLD database or GenBank, so comparison with other specimens was not possible.

\section{Discussion}

\subsection{Distribution and abundance}

Pseudogonalos hahnii is widely distributed in the Baltic states, southern Finland and Russian Karelia (Fig. 2). The northernmost record is from Liperi in Pohjois-Karjala province of eastern Finland. The species is not known from other Nordic countries. It is rare in Finland, and is always found in low numbers. It seems to be scarce also in the Baltic region, but in Estonia, several specimens have been collected in a few localities by Malaise traps. Specimens caught with Malaise traps have also been reported in England and Germany (Shaw 1990, Schnee 2011). 25 of the observations in the study region were made relatively recently, and 29 specimens were collected before 2000. The first specimen was collected in Russian Karelia in 1942, and soon after this the species was found from Finland (1943). In the Baltic states, the species was found notably later (Lithuania 1967, Latvia 1981, Estonia 1988,). Despite the clear increase of the records from 2004 onwards, the species was classified as vulnerable in the latest Red List of Finnish species (Söderman et al. 2010).
Within Europe, P. hahnii has been found from Belgium, Czech Republic, Estonia, Finland, France, Germany, Greece, Italy, Latvia, Lithuania, the Netherlands, Poland, Russia, Slovakia, Switzerland, Ukraine and the United Kingdom. It has also been recorded from China, Kazakhstan, Mongolia and Siberia (Lelej 2003, Madl 2013, Broad 2016).

\subsection{Habitat, egg-laying, phenology and sex ratios}

All published habitat information (Schnee 2011) and collection records make it clear that $P$. hahnii is a eurytopic species that is found in a variety of different environments. However, Finnish records are almost solely from herb-rich meadows (Fig. 3). One Finnish specimen has been caught from a leaf of Salix caprea and an another from a leaf of Ribes.

Pseudogonalos hahnii female lays eggs on the surface foliage of herbaceous and wooden plants (Carmean \& Kimsey 1998, Schnee 2011). The female is extremely fecund with its ovarioles containing more than 10,000 eggs and it can be induced to lay well over a thousand eggs per day in experimental conditions (Bischoff 1936). Eggs are microtypic and $0.1-0.15 \mathrm{~mm}$ in length and 0.05-0.07 in width (Weinstein \& Austin 1991). Eggs also stay viable for a long time (Schnee 2011). Ovipositing has been observed on such di- 
Table 1. Published host records of Pseudogonalos hahnii in chronological order. "Host plant" refers to the observed or inferred oviposition site of $P$. hahnii female.

\begin{tabular}{|c|c|c|c|}
\hline Host plant & $\begin{array}{l}\text { Secondary host } \\
\text { (species and family) }\end{array}$ & $\begin{array}{l}\text { Primary host } \\
\text { (species and subfamily) }\end{array}$ & Reference \\
\hline Poaceae & $\begin{array}{l}\text { Epipsilia latens } \\
\text { (Hübner, 1809) } \\
\text { Noctuidae }\end{array}$ & $\begin{array}{l}\text { Ophion luteus } \\
\text { (Linnaeus, 1758) } \\
\text { Ophioninae }\end{array}$ & Reichert (1911) \\
\hline Not known & $\begin{array}{l}\text { Smerinthus ocellatus } \\
\text { (Linnaeus, 1758) } \\
\text { Sphingidae }\end{array}$ & $\begin{array}{l}\text { Callajoppa cirrogaster } \\
\text { (Schrank, 1781) } \\
\text { Ichneumoninae }\end{array}$ & Puhlmann (1916) \\
\hline Not known & $\begin{array}{l}\text { Papilio machaon } \\
\text { Linnaeus, } 1758 \\
\text { Papilionidae }\end{array}$ & Not known & Berland \& Bernard (1938) \\
\hline Pinus & $\begin{array}{l}\text { Panolis flammea } \\
\text { (Denis \& Schiffermüller, 1775) } \\
\text { Noctuidae }\end{array}$ & $\begin{array}{l}\text { Enicospilus merdarius } \\
\text { (Gravenhorst, 1829) } \\
\text { Ophioninae }\end{array}$ & Gauss (1962) \\
\hline Vaccinium myrtillus & $\begin{array}{l}\text { Ectropis crepuscularia } \\
\text { (Denis \& Schiffermüller, 1775) } \\
\text { Geometridae }\end{array}$ & $\begin{array}{l}\text { Aphanistes bellicosus? } \\
\text { (Wesmael, 1849) } \\
\text { Anomaloninae }\end{array}$ & $\begin{array}{l}\text { Haeselbarth (1979), } \\
\text { Schnee (2015) }\end{array}$ \\
\hline Pinus & $\begin{array}{l}\text { Diprion similis } \\
\text { (Hartig, 1836), } \\
\text { Diprionidae }\end{array}$ & Not known & Carmean \& Kimsey (1998) \\
\hline Pteridium aquilinum & $\begin{array}{l}\text { Ceramica pisi } \\
\text { (Linnaeus, 1758) } \\
\text { Noctuidae }\end{array}$ & $\begin{array}{l}\text { Enicospilus ramidulus } \\
\text { (Linnaeus, 1758) } \\
\text { Ophioninae }\end{array}$ & Schnee (2011) \\
\hline $\begin{array}{l}\text { Rubus idaeus, } \\
\text { R. fructicosus }\end{array}$ & $\begin{array}{l}\text { Polia nebulosa } \\
\text { (Hufnagel, 1766) } \\
\text { Noctuidae }\end{array}$ & $\begin{array}{l}\text { Erigorgus procerus } \\
\text { (Gravenhorst, 1829) } \\
\text { Anomaloninae }\end{array}$ & Schnee (2011) \\
\hline Not known & $\begin{array}{l}\text { Xestia triangulum } \\
\text { (Hufnagel, 1766) } \\
\text { Noctuidae }\end{array}$ & $\begin{array}{l}\text { Erigorgus melanops } \\
\text { (Forster, 1855) } \\
\text { Anomaloninae }\end{array}$ & Schnee (2011) \\
\hline Not known & $\begin{array}{l}\text { Callimorpha dominula } \\
\text { (Linnaeus, 1758) } \\
\text { Erebidae }\end{array}$ & $\begin{array}{l}\text { Heteropelma amictum } \\
\text { (Fabricius, 1775) } \\
\text { Anomaloninae }\end{array}$ & Schnee (2011) \\
\hline Prenanthes purpurea & $\begin{array}{l}\text { Cucullia lactucae } \\
\text { (Denis \& Schiffermüller, 1775) } \\
\text { Noctuidae }\end{array}$ & $\begin{array}{l}\text { Exetastes fornicator } \\
\text { Fabricius 1781) } \\
\text { Banchinae }\end{array}$ & Schnee (2015) \\
\hline
\end{tabular}

verse plants as Pteridium aquilinum (Dennstaedtiaceae), pine needles (Pinaceae), grasses (Poaceae), Phragmites communis (Poaceae), Vaccinium myrtillus, Rubus idaeus, $R$. fruticosus (Rosaceae), Brassicaceae, Prenanthes purpurea (Asteraceae) and Epilobium angustifolium (Onagraceae) (Shaw 1990, Weinstein \& Austin 1991, Schnee 2011, 2015) (Table 1). There are no direct records of oviposition from the study area. During summer 2017, a female was observed flying between and searching on nettles (Urtica dioica) and mugworts (Artemisia vulgaris) in Latvia (U. Piterāns, pers. comm.).
Like in other investigated trigonalid species, the life span of adult Pseudogonalos hahnii is very short, at most 8 days, according to the scant available evidence (Bischoff 1936, Carmean 1991). Trigonalid species of temperate regions normally emerge in spring or summer (Weinstein \& Austin 1991). About $75 \%$ of the specimens caught in Northern Europe are from July (Fig. 4). Keeping in mind the short adult life span and temporal distribution of the records, Pseudogonalos hahnii's actual flight period may very well center around July in North Europe. Most specimens (total 18) from Germany published by Schnee 


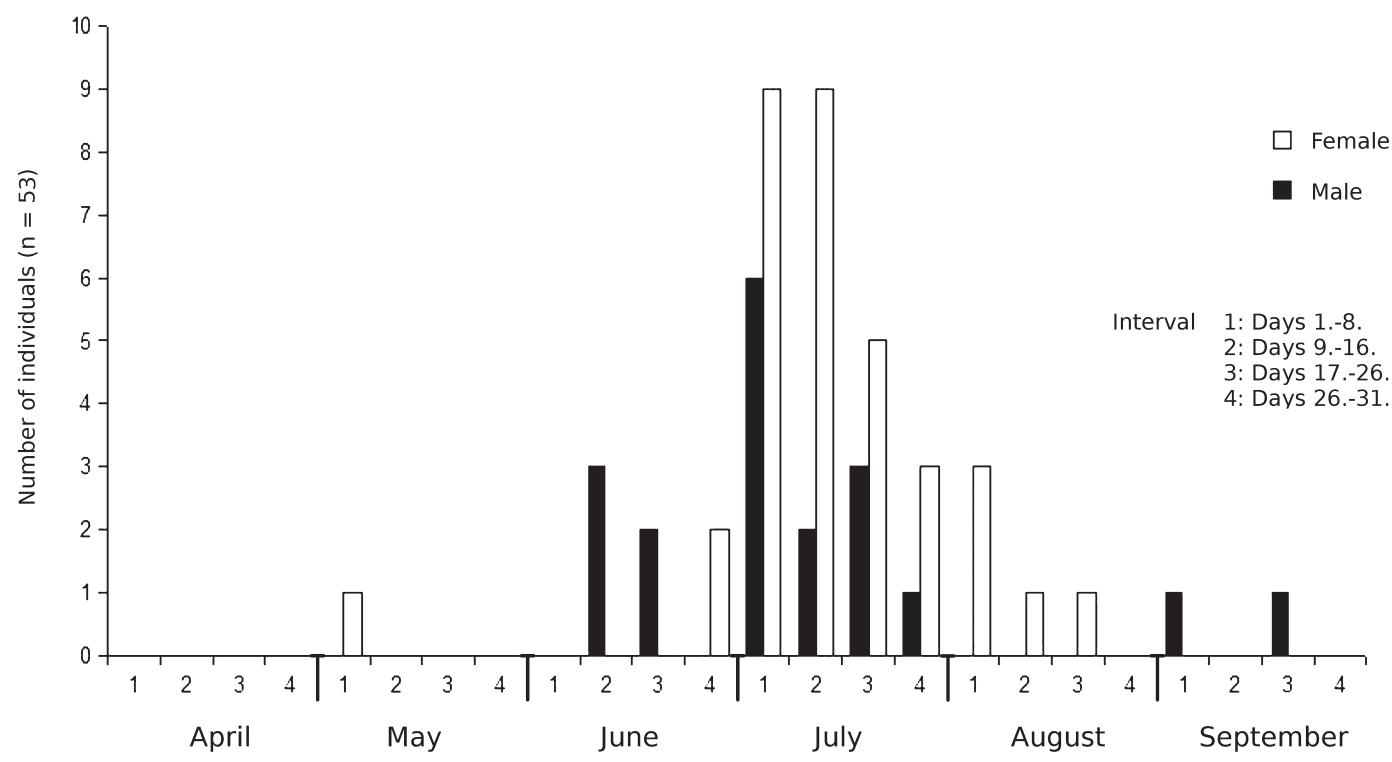

Fig. 4. Phenological distribution of the records of Pseudogonalos hahnii in Fennoscandia and the Baltic countries.

(2011, 2015) were also sampled in July. According to Shaw $(1982,1990)$, many specimens have been caught during August in England. Pseudogonalos hahnii seems to be a protandrous species as the peak of the caught males is earlier in the season than that of the females. The above holds true except for three phenological outliers from Lithuania and Estonia (2 males from September and 1 female from early May).

The sex ratio of collected $P$. hahnii is femalebiased (1.84 females for each male). The pooled sex ratio of field caught specimens reported by Schnee $(2011,2015)$ is about the same ( 2 females for each male). It is not clear why the sex ratios of collected specimens are female biased.

\subsection{Host records}

There are no rearing or host records of $P$. hahnii from the study area. All reported host records are from Germany, United Kingdom, Russia and Poland (Schnee 2011, 2015, D. Carmean, pers. comm., V. Bryukhov, pers. comm.) (Table 1).

All lepidopteran secondary hosts of $P$. hahnii recorded so far are from the families Noctuidae (six species), Erebidae (one species), Geometridae (one species), Sphingidae (one species) and
Papilionidae (one species) (Table 1) (Schnee 2011, 2015). In Kirov region, western central Russia, P. hahnii was photographed emerging from a pupa of Papilio machaon Linnaeus (Papilionidae) on 13 June 2015 (V. Bryukhov, pers. comm.) (Fig. 5). The Canadian National Collection has a specimen of $P$. hahnii from Poland labelled "Host: Diprion similis (Htg.)" (Carmean \& Kimsey 1998, D. Carmean \& J. Huber, pers. comm.). In Germany, thousands of hibernating Diprion (Diprionidae) cocoons have been investigated for decades by forestry protection in pine forests and no $P$. hahnii has ever been reared, and therefore the record of the sawfly $D$. similis as a host of $P$. hahnii could be regarded as unconfirmed (H. Schnee, pers. comm.). However, as all Trigonalidae rearing records are always very rare occurrences, we see no reason for discounting the $D$. similis host record. It is not known, whether $P$. hahnii developed as a primary parasitoid of $D$. similis or parasitized an unknown primary parasitoid of $D$. similis.

Primary hosts of $P$. hahnii recorded so far are all from the family Ichneumonidae: Ophioninae (three species), Ichneumoninae (one species), Banchinae (one species) and Anomaloninae (three species plus one likely additional species) (Haeselbarth 1979, Schnee 2011, 2015) (Table 

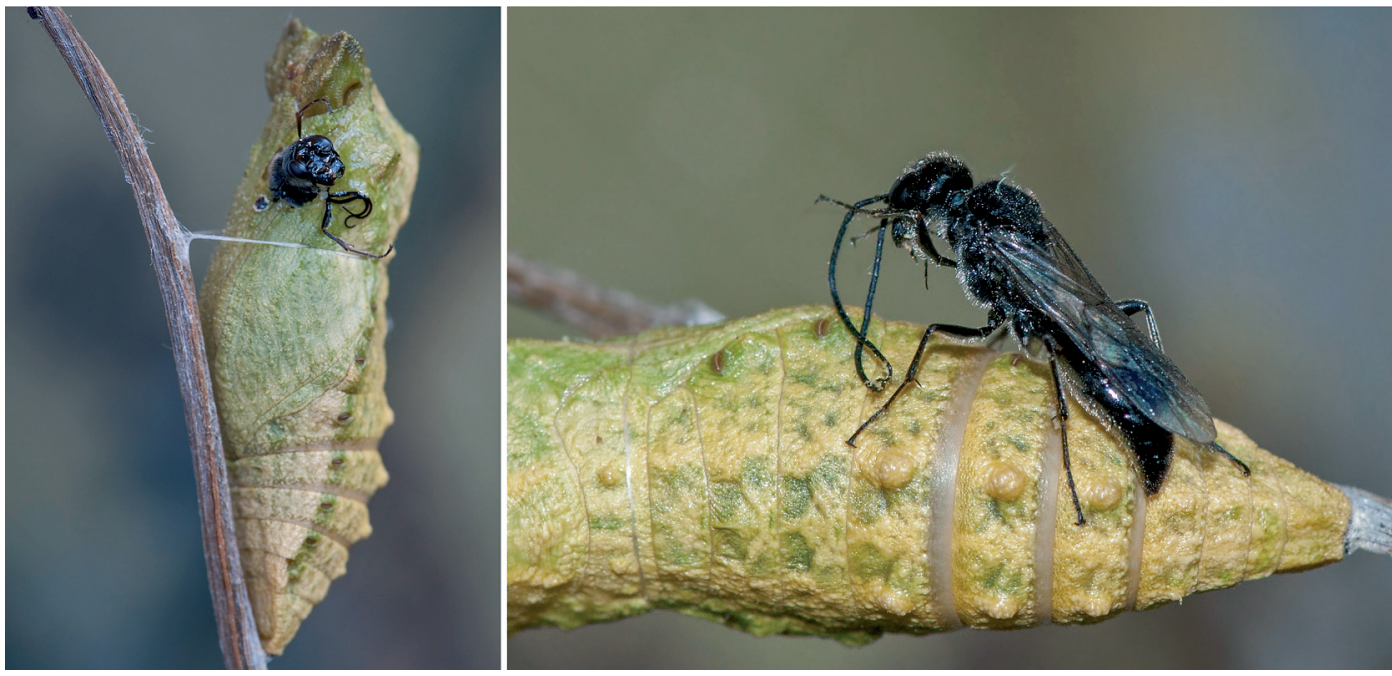

Fig. 5. Pseudogonalos hahnii emerging from Papilio machaon pupa. 13 June 2015. Kirov region, Russia. Photo: Vladimir Bryukhov.

1). All these four subfamilies are koinobiont endoparasitoids (Gauld \& Bolton 1988). Species that parasitize lepidopteran caterpillars from the endoparasitic koinobiont subfamilies Campopleginae and Metopiinae are other possible primary hosts. On the contrary, species from ectoparasitic or idiobiont ichneumonid subfamilies parasitizing Lepidoptera are not likely to act as primary hosts (Schnee 2011). Ctenopelmatine ichneumonids could serve as possible primary hosts via sawfly larva as the members of the subfamily are larval koinobiont endoparasitoids of sawflies (Gauld \& Bolton 1988, Schnee 2011). Another possible primary host group for $P$. hahnii are tachinid flies that attack lepidopteran (or even symphytan) larvae (Weinstein \& Austin 1991, Schnee 2011) as several trigonalid wasp species have indeed been reared from tachinid puparia (Li et al. 2012, Smith et al. 2012). There are some erroneous or at least highly dubious old records that $P$. hahnii could parasitize vespine wasps (Vespidae) or their parasitoids. There is also one report of $P$. hahnii parasitizing the neotropical paper wasp Polistes lanio (Fabricius) that Carmean and Kimsey (1998) consider clearly improbable.

If host records of $P$. hahnii can be considered scanty, even less is known about the host relationships of the two other Pseudogonalos species. There are no host records for $P$. angusta or $P$. har- mandi. Weinstein and Austin (1991) cite Popov's (1945) rearing records of $P$. harmandi from Trogus sp. (Ichneumoninae) and Ophion sp. (Ophioninae), but these records are erronoeus (Carmean \& Kimsey 1998).

Pseudogonalos hahnii is rarely collected, probably because as a hyperparasitoid with a remarkable strategy, it needs a herbivorous host to be parasitized by a primary parasitoid (the primary host) before it can complete its development. The trigonalid larva will develop to adulthood regardless whether the herbivorous secondary host was parasitized by the ichneumonid primary parasitoid before or after it ingested the trigonalid eggs. The trigonalid larva can stay viable within the herbivorous secondary host for several months and wait for the ichneumonid parasitoid female to oviposit into the same secondary host (Schnee 2011). High fecundity of the female and wide host spectrum make it more likely that at least some of the $P$. hahnii progeny will reach adulthood every year. Future collection efforts, rearings and laboratory studies will surely widen considerably the known primary and secondary host spectrum and other aspects of the biology of $P$. hahnii.

Acknowledgements. We are very grateful to Dave Carmean and Heinz Schnee for their suggestions to improve the manuscript and for much other help they have provided 
during the preparation of this article; David R. Smith for his suggestions to improve the manuscript; to Pekka Malinen and Vladimir Bryukhov for letting us use their excellent photographs; to Mikk Heidemaa, Veli Vikberg and John Huber for the information about specimens; and to Sampsa Lommi for preparing the distribution map. DNA barcode data used in this publication was generated in collaboration with the Finnish Barcode of Life project (FinBOL) funded by the Kone Foundation and the University of Oulu. We also thank the reviewers Gergely Várkonyi and Mattias Forshage for their helpful and critical review of the manuscript.

\section{References}

Abenius, J. \& Spunggis, V. 2001: First record of Pseudogonalos hahnii (Spinola, 1840) (Pseudogonalidae) in Latvia. - Latvijas Entomologs 38: 38.

Aguiar, A. P., Deans, A. R., Engel, M. S., Forshage, M., Huber, J. T., Jennings, J. T., Johnson, N. F., Lelej, A. S., Longino, J. T., Lohrmann, V., Mikó, I., Ohl, M., Rasmussen, C., Taeger, A. \& Yu, D. S. K. 2013: Order Hymenoptera. In: Zhang, Z.-Q. (ed.), Animal biodiversity: an outline of higher-level classification and survey of taxonomic richness (addenda 2013). - Zootaxa 3703: 51-62.

Anonymous 1950: Kokousselostuksia, Trigonalis hahni löydetty Vanajasta. - Annales Entomologici Fennici 16: 36.

Berland, L. \& Bernard, F. 1938: Hyménoptères vespiformes. III. (Cleptidae, Chrysidae, Trigonalidae). — Faune de France 34: 147 pp.

Bischoff, H. 1936: Beiträge zur Lebensgeschichte der Pseudogonalos hahni (Spin.). - Sitzungsberichte der Gesellschaft Naturforschender Freunde zu Berlin 1936: 51-63.

Branstetter, M. G., Danforth, B. N., Pitts, J. P., Faircloth, B. C., Ward, P. S., Buffington, M. L., Gates, M. W., Kula, R.R. \& Brady, S. G. 2017: Phylogenomic insights into the evolution of stinging wasps and the origins of ants and bees. - Current Biology 27: 10191025.

Broad, G. R. 2016: Checklist of British and Irish Hymenoptera-Trigonaloidea. - Biodiversity Data Journal 4: e7935.

Carmean, D.1991: Biology of the Trigonalyidae (Hymenoptera), with notes on the vespine parasitoid Bareogonalos canadensis. - New Zealand Journal of Zoology 18: 209-214.

Carmean, D. \& Kimsey, L. 1998: Phylogenetic revision of the parasitoid wasp family Trigonalidae (Hymenoptera). - Systematic Entomology 23: 35-76.

Chen, H.-y., Achterberg, C. van, He, J.-h. \& Xu Z.-h. 2014: A revision of the Chinese Trigonalyidae (Hymenoptera, Trigonalyoidea). - ZooKeys 385: 1-207.

Gauld, I. D. \& Bolton, B. (eds) 1988: The Hymenoptera. — Oxford University Press + British Museum (Natural History). 332 pp.
Gauss, R. 1962: Über Pseudogonalos hahni (Spin.) (Hym: Trig.) und seine Wirte. - Mitteilungen des badischen Landesvereins für Naturkunde und Naturschutz 8: 275-288.

Gelhaus, J. K. 1987: A detritivore Tipula (Diptera: Tipulidae) as a secondary host of Poecilogonalos costalis (Hymenoptera: Trigonalidae). — Entomological News 98: 161-162.

Haeselbarth, E. 1979: Zur Parasitierung der Puppen von Forleule (Panolis flammea [Schiff.]), Kiefernspanner (Bupalus pinarius [L.]) und Heidelbeerspanner (Boarmia bistortata (Goeze)) in bayerischen Kiefenwäldern. Teil 1. - Zeitschrift für angewandte Entomologie 87: 186-202.

Heraty, J. M. \& Murray, E. 2013: The life history of Pseudometagea schwarzii, with a discussion of the evolution of endoparasitism and koinobiosis in a specialized group of chalcid wasps. - Journal of Hymenoptera Research 35: 1-15.

de Jong, Y., Verbeek, M., Michelsen, V., de Place Bjųrn, P., Los, W., Steeman, F., Bailly, N., Basire, C., Chylarecki, P., Stloukal, E., Hagedorn, G., Wetzel, G. T., Glöcker, F., Kroupa, A., Korb, G., Hoffmann, A., Häuser, C., Kohlbecker, A., Müller, A., Güntsch, A., Stoev, P. \& Penev, L. 2014: Fauna Europaea - all European animal species on the web. - Biodiversity Data Journal 2: e4034. doi: 10.3897/BDJ.2.e4034.

Klopfstein, S., Vilhelmsen, L., Heraty, J. M., Sharkey, M. \& Ronquist, F. 2013: The hymenopteran tree of life: evidence from protein-coding genes and objectively aligned ribosomal data. — PLoS One 8: e69344.

Lelej, A. S. 2003: A review of the Family Trigonalyidae (Hymenoptera) of the Palaearctic Region. - Far Eastern Entomologist 130: 1-7.

Li, T., Sheng, M-L., Sun, S-P. \& Luo \& Y-Q. 2012: Parasitoids of the sawfly, Arge pullata, in the Shennongjia National Nature Reserve. - Journal of Insect Science 12: 97.

Madl, M. 2013: Trigonaloidea. — In: Mitroiu, M.-E. (ed.), Fauna Europaea: Hymenoptera Apocrita excl. Ichneumonoidea. Fauna Europaea version 2.6, http://www. fauna-eu.org.

Nel, A, Perrichot, V. \& Néraudeau, D. 2003: The oldest trigonalid wasp in the Late Albian amber of CharenteMaritime (SW France) (Hymenoptera: Trigonalidae). — Eclogae Geologicae Helvetiae 96: 503-508.

Perrichot, V., Ortega-Blanco, J., McKellar, R. C., Delcós, X., Azar, D., Nel, A., Tafforeau, P. \& Engel, M. S. 2011: New and revised maimetshid wasps from Cretaceous ambers (Hymenoptera, Maimetshidae). — ZooKeys 130: 421-453.

Peters, R. S., Krogmann, L., Mayer, C. Donath, A., Gunkel, S., Meusemann, K., Kozlov, A., Podsiadlowski, L., Petersen, M., Lanfear, R., Diez, P. A., Heraty, J., Kjer, K. M. Klopfstein, S., Meier, R., Polidori, C. Schmitt, T., Liu, S., Zhou, X., Wappler, T., Rust, J., Misof, B. \& Niehuis, O. 2017: Evolutionary History of Hymenoptera. - Current Biology 27: 1013-1018. http://dx.doi.org/10.1016/j.cub.2017.01.027

Popov, V. V. 1945: (Zoogeographical and morphological 
patterns of family Trigonalidae (Hymenoptera)). Doklady Akademii nauk SSSR 48(1): 75-78. [In Russian.]

Puhlmann, E. 1915-1916: Pseudogonalos hahni Spin. Abhandlungen des Vereins für naturwissenschaft. Erforschung des Niederrheins in Verbindung mit dem Städtischen Naturwissenschaftlichen Museum 1915/16: 50.

Quicke, D. L. J., LeRalec, A. \& Vilhelmsen, L. 1999: Ovipositor structure and function in the parasitic Hymenoptera. - Rendiconti 47: 197-239.

Reichert, A. 1911: Beitrag zur Lebensweise von Pseudogonalos hahni SPIN. - Berliner Entomologische Zeitschrift 56: 109-112.

Schnee, H. 2011: Beitrag zur Kenntnis der Biologie von Pseudogonalos hahnii (Spinola) (Hymenoptera, Trigonalidae und Ichneumonidae). - Entomologische Nachrichten und Berichte 55: 27-32.

Schnee, H. 2015: Neue Wirte von Pseudogonalos hahnii (Spinola, 1840) (Hymenoptera, Trigonalidae und Ichneumonidae, Lepidoptera, Noctuidae). - Entomologische Nachrichten und Berichte 59: 235-236.

Sharkey, M. 2007: Phylogeny and classification of Hymenoptera. - Zootaxa 1668: 521-548.

Shaw, M. R. 1982: Pseudogonalos hahnii (Spinola) (Hym., Trigonalidae) in Norfolk — Entomologist's Monthly Magazine 117: 155.

Shaw, M. R. 1990: More Trigonalis hahnii Spinola (Hym., Trigonalyidae) in Norfolk. - Entomologist's Monthly Magazine 126: 86.

Shaw, M. R. 2014: Illustrated notes on the biology of two European species of Euceros Gravenhorst (Hymenoptera: Ichneumonidae: Eucerotinae). — Proceedings of the Russian Entomological Society 85: 122-132.

Smith, D. R. \& Stocks, I. C. 2005: A new trigonalid wasp
(Hymenoptera : Trigonalidae) from eastern North America. - Proceedings of the Entomological Society of Washington 107: 530-535.

Smith, D. R., Janzen, D. H., Hallwachs, W. \& Smith, A. M. 2012: Hyperparasitoid wasps (Hymenoptera, Trigonalidae) reared from dry forest and rain forest caterpillars of Area de Conservación Guanacaste, Costa Rica. - Journal of Hymenoptera Research 29: 119-144.

Söderman, G., Várkonyi, G. \& Koponen, M. 2010: Kätköpistiäiset - Parasitoid wasps - Hymenoptera: Parasitica. - In: Rassi, P., Hyvärinen, E., Juslén, A. \& Mannerkoski, I. (eds), The 2010 Red List of Finnish Species: 519-528. Ympäristöministeriö \& Suomen ympäristökeskus, Helsinki. 685 pp.

Stireman, J. O. III, O’Hara, J. E. \& Wood, D. M. 2006: Behavior, ecology and evolution of tachinid parasitoids. - Annual Review of Entomology 51: 525-555.

Vilhelmsen, L., Perrichot, V. \& Shaw, S. R. 2010: Past and present diversity and distribution in the parasitic wasp family Megalyridae (Hymenoptera). — Systematic Entomology 35: 658-677.

Weinstein, P. \& Austin, A. D. 1991: The host relationships of trigonalyid wasps (Hymenoptera: Trigonalyidae), with a review of their biology and catalogue to world species. - Journal of Natural History 25: 399-433.

Winterhagen, P. 2015: Strategy for sneaking into a host's home: The cuckoo wasp Omalus biaccinctus (Hymenoptera: Chrysididae) inserts its eggs into living aphids that are the prey of its host. - European Journal of Entomology 112: 557-559.

Zimmermann, D. \& Vilhelmsen, L. 2016: The sister group of Aculeata (Hymenoptera) - evidence from internal head anatomy, with emphasis on the tentorium. Arthropod Systematics \& Phylogeny 74: 195-218. 